Article

\title{
Wind Turbines on German Farms-An Economic Analysis
}

\author{
Clemens Fuchs *, Karl Marquardt, Joachim Kasten and Katharina Skau \\ University of Applied Sciences, Departement of Agricultural Economics, 17033 Neubrandenburg, Germany; \\ karlmarquardt@gmx.de (K.M.); kasten@hs-nb.de (J.K.); skau@hs-nb.de (K.S.) \\ * Correspondence: cfuchs@hs-nb.de; Tel.: +49-395-5693-2102
}

Received: 21 February 2019; Accepted: 19 April 2019; Published: 26 April 2019

\begin{abstract}
Only a small number of German farmers invest in wind turbines on the land they own; rather, they tend to lease land for that purpose to external investors. In this study, an explorative qualitative analysis of the reasons for this investment pattern was conducted. Calculations of the economic efficiency (e.g., net present value, payoff) of wind turbines built the foundation of the study. In addition, farmers in the northeastern federal state of Mecklenburg-Western Pomerania were interviewed to assess their motives for capital expenditure. A considerable amount of equity capital is required to set up a wind turbine. The capital invested frequently competes with the purchase of agricultural land. Erecting wind turbines involves risks. Substantial financial means for planning permission and other examinations precede the construction of a wind turbine. Only at the very end of these costly investigations will a construction permit be issued; as such, farmers face a high level of uncertainty during the whole process. Fluctuations in wind yield resulting in volatile revenues confront farmers with additional financial uncertainties. The risk-taking behavior of farmers was assessed normatively by the Hurwicz criterion. The results showed that farmers with the necessary funds at their disposal and a high level of optimism were more likely to take the risk to set up a wind turbine on their own land. They make this decision despite the fact that leasing one's own land to external investors is predictably profitable and clearly less risky.
\end{abstract}

Keywords: renewable energy; investment; leasing; profitability; risk

\section{Introduction}

Growing public concern has led governments worldwide, at the EU level and individual national governmental agencies, to set policies and a solid legislative framework to reduce emissions of greenhouse gasses [1,2]. Since 1991, Germany has been promoting the generation of renewable energy. The basis for this was first the Electricity Supply Act (1991), and since the year 2000, the Act on the Development of Renewable Energy Sources (Renewable Energy Sources Act-RES Ac-EEG [3]). "The purpose of this law is to enable the sustainable development of energy supply, in particular in the interests of climate and environmental protection, to reduce the economic costs of energy supply by including long-term external effects, to conserve fossil energy resources and to develop technologies for the production of electricity from Renewable Energy." [3]. "The aim of this law is to increase the share of electricity generated from renewable energies in gross electricity consumption to 40 to 45 percent by 2025." [3]. The topic "wind" is because of the EEG-legislation relevant in Germany and there are only a few international studies.

Gross electrical power generation in Germany of all fossil and renewable energy sources together increased from 576.6 TWh in the year 2000 to $651.8 \mathrm{TWh}$ in 2015. The share of renewable energy sources (from hydropower, wind, solar, biogas, and other biomass) rose from $6.5 \%$ to $32.6 \%$. Wind power accounted for 9.5 TWh in 2000 (onshore only) and increased to 79.3 TWh onshore and 8.7 TWh offshore 
in 2015. Wind turbines thus produced the largest share of renewable energies in 2015, followed by biomass (44.2 TWh) and photovoltaic (38.4 TWh) sources [4].

Significant investments have been made in the biogas sector, where up to about 10,000 units have been built in the past 20 years in Germany. However, since 2015, electricity prices for new biogas plants have been significantly lower, so investments in this sector of renewable energies have come to a halt.

The number of wind turbines has risen from 9359 in 2000 to 28,675 in 2017 (Figure 1). In order to achieve the politically predetermined goal of up to an $80 \%$ share of renewable electricity by 2050 , more wind turbines have to be built.

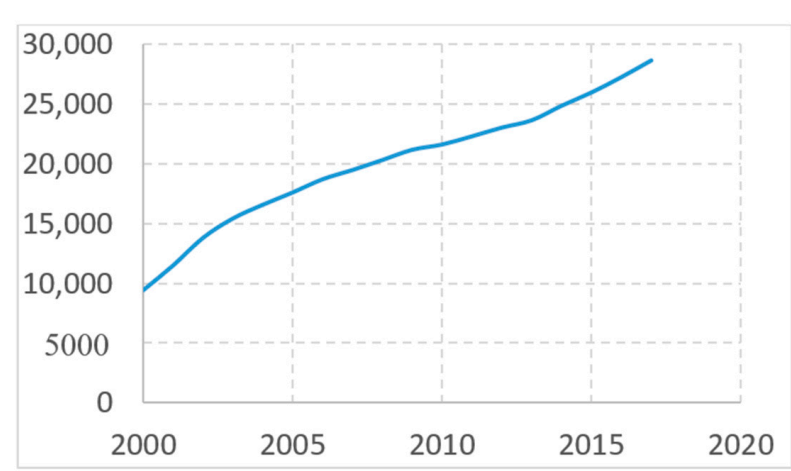

Figure 1. Development of the number of onshore wind turbines in Germany in the years 2000-2017 [5].

While the number of wind turbines is increasing, the share of wind turbines owned by farmers is relatively low compared to other renewable energies. While in some regions the share of solar energy facilities owned by farmers amounts up to $40 \%$, wind energy is less than $4 \%$ even in the naturally preferred wind locations in the north of Germany (Table 1). While there are so few farmers as investors it was only possible to do an explorative survey with farmers [6]. Due to the privatization policy for land markets special constraints can be determined for the eastern Germany regions as for example the federal state of Mecklenburg-Western Pomerania, where the wind turbines used in calculations here are located. Due to the small number of farmers who have invested in wind turbines in the last years, the authors were not able to find more farmers to interview in an appropriate time horizon.

Table 1. Share of renewable energy generated by farmers in the respective federal state (region).

\begin{tabular}{ccccc}
\hline Region (North to South) & Wind energy & Solar energy & Biomass & Hydropower \\
\hline Schleswig-Holstein & $3.8 \%$ & $34.6 \%$ & $3.8 \%$ & - \\
\hline Mecklenburg-Vorpommern & - & $4.6 \%$ & $2.1 \%$ & - \\
\hline Brandenburg & - & $7.4 \%$ & $1.9 \%$ & - \\
\hline Niedersachsen & $1.8 \%$ & $28.1 \%$ & $4.1 \%$ & - \\
\hline Sachsen-Anhalt & - & $7.1 \%$ & $2.4 \%$ & - \\
\hline Sachsen & - & $6.3 \%$ & $3.2 \%$ & - \\
\hline Nordrhein-Westfalen & $1.5 \%$ & $35.9 \%$ & $2.0 \%$ & - \\
\hline Thüringen & - & $8.8 \%$ & $2.9 \%$ & - \\
\hline Hessen & - & $24.1 \%$ & $1.2 \%$ & - \\
\hline Rheinland-Pfalz & - & $19.9 \%$ & $0.5 \%$ & - \\
\hline Saarland & - & $25.0 \%$ & - & - \\
\hline Bayern & - & $40.2 \%$ & $3.6 \%$ & \\
\hline Baden-Württemberg & - & $32.6 \%$ & $2.6 \%$ & - \\
\hline & - no data available & & - \\
\hline
\end{tabular}

Source: Federal Ministry of Food and Agriculture (BMEL 2017) Research Fields Issue 4-November 2017, p. 15; data from the Farm Structure Survey 2013 [7]. 


\section{Wind Power Increases while Biogas Stagnates}

The generation of renewable energies is steadily increasing in the federal state of Mecklenburg-Western Pomerania in a way similar to that at the national level. Mecklenburg-Western Pomerania was selected as the site of this qualitative study. In this study, the economic efficiency of an exemplary wind turbine was calculated and farmers at wind park locations were interviewed [6]. The strongest expansion is currently driven by investments in wind energy (Figure 2).

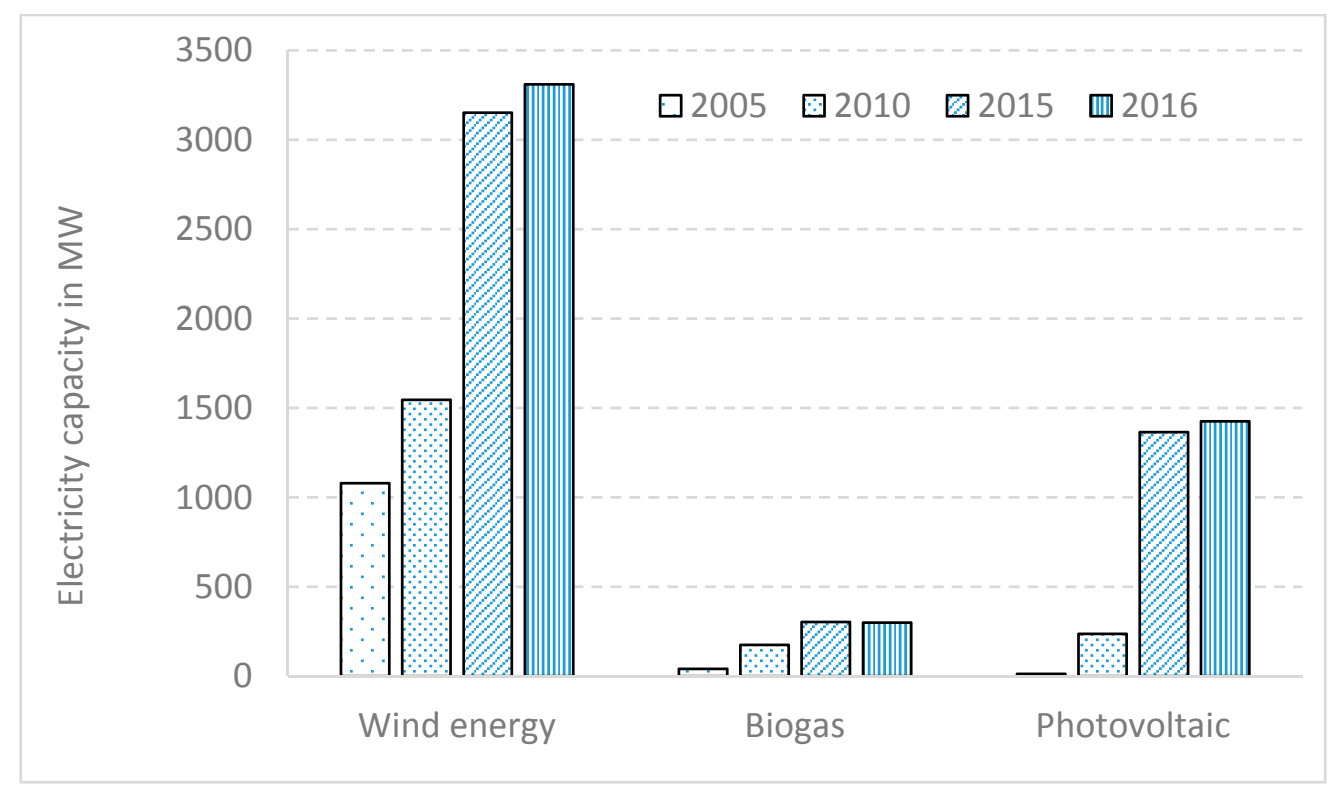

Figure 2. Development of electricity generation from renewable energies in the federal state of Mecklenburg-Western Pomerania [8].

The expansion of wind energy means the destruction of agricultural land and soil and therefore loss of income from plant production. On the other hand, income opportunities for agricultural firms as well as municipalities arise through wind energy production. Since farmers and agricultural companies are often owners of land, they have the opportunity to invest in their own wind turbines or to lease the location for wind turbines to external investors-investors from outside of the agricultural sector.

As previously mentioned, farmers, as landowners, can design and build their own wind turbines in designated wind energy areas. However, the necessary investments for a modern wind turbine with the capacity of about $3 \mathrm{MW}$ sums up to millions of Euros. Even at the planning stage, considerable costs are incurred for appraisals and approvals, amounting to approximately 7\% [6] of the total investment that would be lost in the event of non-approval [9].

Therefore, our hypothesis was that farmers must be prepared to take special risks related to, for example, uncertain results of the permit procedure, the required equity, or the profitability of investment when planning to set up at least a single wind turbine. For more than one wind turbine (e.g., as part of a wind farm), the initial available equity would probably not be sufficient in most cases. Therefore, we assumed that the lease of locations might usually be preferred. In contrast to that, for larger external investors and professional planning agencies of wind turbine parks, the risk of unapproved planning is spread over larger units and is also calculable on the basis of existing expertise.

Also, Reference [9] describes the increasing investment in wind turbines. However, they note that, for farmers, wind farm financing mostly involves private property and does not include agricultural assets. By definition, there are no liability or economic risk relationships with the farm for real project financing for wind turbines. For this reason, farmers could develop a second sector by building a wind farm. However, inhibitions about entering a completely new industry are even higher. 
The regulations for constructing a wind turbine are an integral part of planning a wind farm or a single wind turbine and bind a great amount of capital in advance. The most important assessments and reports and the progress of the approval phase are briefly explained below. After that, the suitability of currently designated wind turbines for a location in Mecklenburg-Western Pomerania is shown.

\section{Methodology}

After introducing the overall political conditions and economic development in the energy sector and the related environmental protection measures, the methodology of the study is described in this section. This study was based on (1) the cost calculations of wind turbines in order to assess profitability and (2) farmer interviews to learn more about motivations for or against an investment in wind farms.

A deterministic calculation of total costs and a breakeven analysis for the construction of a typical wind turbine in northeastern Germany was needed to assess the economic situation and the chances of profitability of such an investment. Furthermore, in a stochastic simulation [10] with a triangle distribution of electrical power production (median $3200 \mathrm{~h}$ p.a. (per annum) and a deviation of \pm 500 full-load hours), the risk of fluctuating wind yields should be calculated. Additionally, a net present value comparison of personal investment versus revenues from leasing a wind turbine site, taking into account risk tolerance according to the Hurwicz criterion [11], gave insight into the decision alternatives of personal investment or leasing options.

As observed in other countries (e.g., the United States, Sweden, and Wales) [12-14] as well as in Germany, farmers are rarely owners of wind turbines or even wind parks. To learn more about the motivations, benefits, and obstacles of personally investing in wind turbines, three farmers were interviewed using a structured questionnaire developed by the authors.

\subsection{Large Approval Effort}

During the planning process of wind turbines and wind parks, operators are confronted with a multitude of laws and regulations at the federal, state, and local levels (Figure 3).

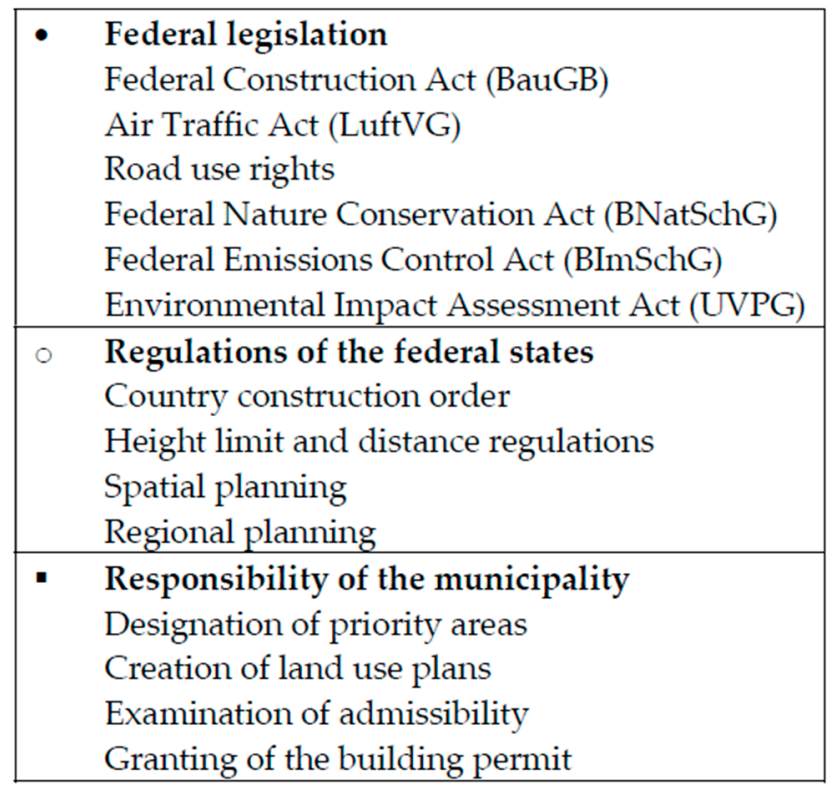

Figure 3. Regulations for the approval of wind turbines [15].

Since 1998, wind turbines in rural areas have been considered privileged projects under the Federal Construction Act (BauGB). This amendment encouraged the creation of wind power projects. Since then, planned projects in designated suitable wind energy areas can no longer be prevented by individuals. 
The technical part of the required planning documents includes a ground survey, the course of the cable routes, as well as the proof of ownership and lease conditions of the wind turbine location. For this purpose, a description of the location (geographical location and land use maps) is required, which includes information on crane movement, crane shelves, construction documents of the wind turbines, and a mapping of the areas with the corresponding distance requirements [15].

The second component of the approval procedure is an environmental impact assessment according to the Federal Emissions Control Act (BImSchG). All basic requirements are regulated but may vary from state to state or are supplemented by the respective BauGB or country construction order. A variety of relevant environmental and regulatory documents are necessary, in particular for occupational safety, air traffic control, a wind report, turbulence, ice shedding, noise emission, the building materials used, waste treatment, visualization, plant safety, lightning and fire protection, a landscape maintenance plan, archaeological features (possibly), end of operation, species protection, settlement structure, habitat compatibility, conservation, classification of flora and fauna, biotope structure, soil management, physical characterization, water management, and soil sealing [15].

\subsection{New Designated Areas for Wind Energy below 1\% of the Land Area of Mecklenburg-Western Pomerania}

On local levels, there has been considerable public resistance to the declaration of new designated wind turbine park areas. The areas involved constitute less than $1 \%$ of the land area of Mecklenburg-Western Pomerania, as shown for five larger sub-regions in Mecklenburg-Western Pomerania:

- The planning region Western Pomerania covers an area of 713,700 ha, in which the administrative district of Western Pomerania-Greifswald (VG) has an area of 393,000 ha and the district of Western Pomerania-Rügen (VR) occupies an area of 320,700 ha. In the districts of VR and VG, an area of 6258 ha was designated as a suitable wind energy area in the "Second Amendment to the Regional Spatial Development Program of Western Pomerania, 2015". The wind suitability areas thus comprise approximatively $0.87 \%$ of the area of the planning region of Western Pomerania.

- In Germany's largest district, the Mecklenburg Lake District (Mecklenburgische Seenplatte (MSE)), with an area of 547,000 ha, an area of 4465 ha is designated as a suitable area for wind power plants. This corresponds to $0.82 \%$ of the district of MSE.

- For the district and the city of Rostock, suitable areas for wind energy production of approximatively $1 \%$ of the area of the planning region are indicated. With an area of the planning region of 360,400 ha, this corresponds to an area of approximatively 3500 ha. According to the Spatial Development Program "Region Rostock", wind turbines with a total output of 1000 MW can be built. This is twice the output of the Rostock hard-coal-fired power plant.

- For the planning region Westmecklenburg, an area of 6473 ha was designated as a suitable area for wind energy production in the partial update of the regional spatial development program of Westmecklenburg in 2016. The planning region itself has an area of 700,200 ha, making it the largest of the four planning regions in Mecklenburg-Western Pomerania. The area share of the wind suitability areas here amounts to approximatively $0.92 \%$.

\section{Lease Income Compared with the Profitability of Owning a Wind Turbine}

In this section, the construction of one's own wind turbine is compared with the leasing of a site. The assumptions are based on real data from wind turbines in the federal state of Mecklenburg-Western Pomerania. As an example, the construction of a wind turbine with a capacity of $2.3 \mathrm{MW}$ was considered (Table 2). For this purpose, a full financing plan was drawn up and evaluated. The total investment was $€ 3,604,100$, which included pro rata $7 \%$ planning and approval costs of $€ 252,287$, which must be invested in advance without any guarantee that the project will be carried out. 
Table 2. Assumptions for the breakeven calculation of a wind turbine.

\begin{tabular}{lcc}
\hline \multicolumn{1}{c}{ Key Figures } & Unit & Amount \\
\hline Size of the wind turbine & MW & 2.3 \\
Total investment & $€$ & $3,604,100$ \\
From that: Planning and approval costs & Percentage/amount in $€$ & $7 \% / 252,287$ \\
Initial equity of external investors/farmers & $\%$ p.a. & 570,615 \\
Interest rate of loans & Years & 2.5 \\
Amortization period & & 20 \\
Feed-in tariffs & $€ / \mathrm{kWh}$ & \\
$-\quad$ First five years & $€ / \mathrm{kWh}$ & 0.0890 \\
$-\quad$ Following years & Full-load hours per year & 0.0495 \\
Capacity utilization & & 3200 \\
\hline
\end{tabular}

Initially, $15 \%$ of one's initial equity plus $€ 30,000$ for the dismantling of the windmill at the end of use have to be brought in for the investment, which add up to an equity amount of $€ 570,615$ (Figure 4). This is a substantial sum even for a larger agricultural enterprise, which then will not be available for other alternative investments (e.g., buying land or investments in buildings or machinery), something which was also confirmed in the survey by the farmers.

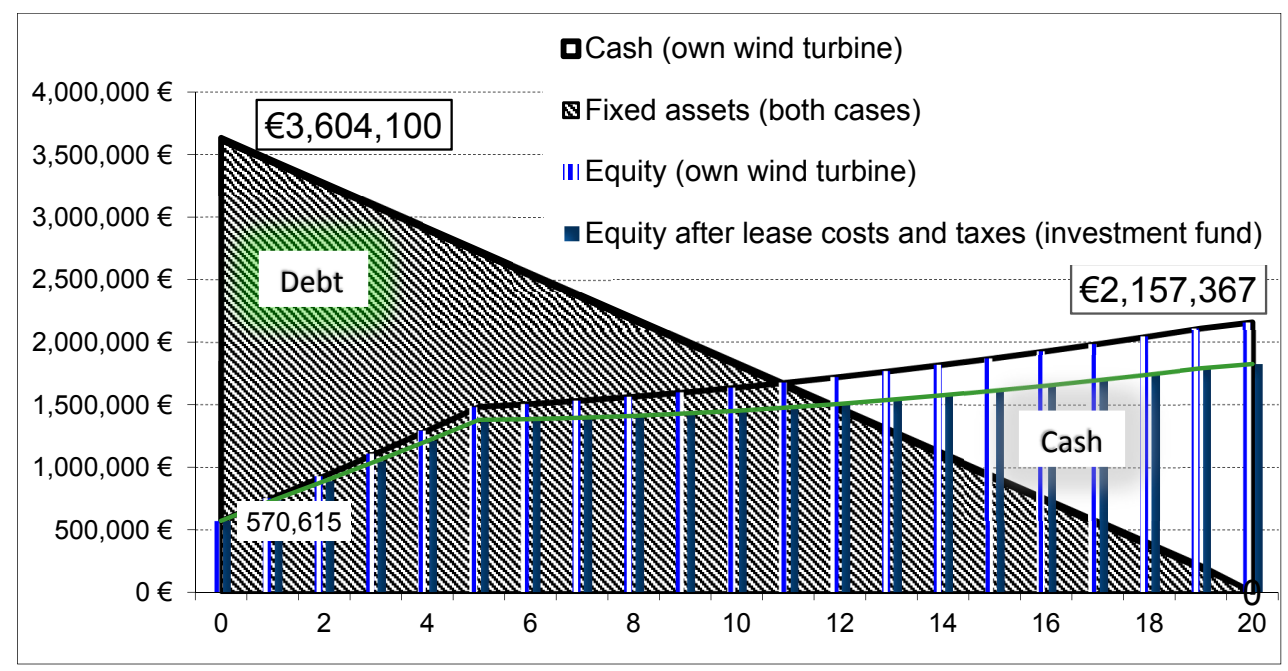

Figure 4. Amount of investment at the beginning, necessary equity capital and development of fixed assets, and cash surplus for a wind turbine depending on the investor (farmer or external investor, example of lease share amounting to $5.5 \%$ of the electricity revenue).

The operation costs of the wind turbine were derived from depreciation, which was calculated for a use period of 20 years, the interest of $2.5 \%$ for borrowed capital, and $2 \%$ utilization costs for equity capital or the calculation of net present values, as well as other costs of $€ 56$ per $\mathrm{kW}$ per year for operations management, insurance, reserves, maintenance and repair, and so forth [16]; the latter adds up to $€ 128,800$ p.a. In addition, direct marketing costs of $0.20 €$ cent per $\mathrm{kWh}$ (approximately $€ 14,720$ p.a.) must be taken into account.

When leasing a site for a wind turbine, $5.5 \%$ of the electricity revenue is initially recognized as lease costs or revenue, which in the first five years results in an average lease income of $€ 36,027$ p.a., and in the remaining term, $€ 20,038$ p.a. Depending on the competitive situation, the rental share of electricity revenue can fluctuate considerably; in the following calculation, a range of $4 \%-8 \%$ was evaluated. In some cases, even values for the leasing share of up to $10 \%$ have been mentioned. Because of lease payments, the equity capital of an external investor (fund) is lower compared with the equity capital of a farmer who operates a wind turbine on his own land (Figure 4). 
The difference in compensation over the useful life expectancy is also evident from the development of equity: The Renewable Energy Sources Act (EEG, [3]) guarantees, for the first five years, a selling price of $€ 0.089$ per $\mathrm{kWh}$ for the produced electricity, and in the following years, $€ 0.0495$ per $\mathrm{kWh}$ (EEG 2014). It is currently not possible to estimate the remuneration that can be achieved under the EEG 2017, as new projects have to participate in the tenders, and only then will the new allowances be determined. Capacity utilization is assumed to be 3200 full-load hours per year, resulting in a capacity utilization of $37 \%$ p.a. equivalent. The revenues are then initially at $€ 655,040$ p.a. and fall from the sixth year to $€ 364,320$ p.a.

The calculated results of the average profit before taxes are approximately $€ 76,000$ p.a., from which a payback period of 14 years can be derived. Including the equity capital, the possibility of special repayments, and the higher initial remuneration, the investor could already be debt-free after 11 years (farmer with his own wind turbine) or 12 years (external investor-investment fund) (Figure 4).

All in all, in the case of investment by a farmer, an increase in equity (after taxes) can be expected to amount to around $€ 1.5$ million and from external investors by as much as $€ 1.2$ million. Investing in a wind turbine proves to be comparatively lucrative, as it comes to a return on equity of $6.9 \%$ for the investing farmer.

In the investment calculation, the net present value was used to assess profitability. The net present value is based on the start of the investment $(\mathrm{t} 0)$ and results from the discounted surpluses. With $€ 1.5$ million equity growth over 20 years of operation, the (discounted) net present value is $€ 881,231$ for t0. This represents the value of the location of a windmill to the farmer. Potential risks, for example, fluctuating wind yields or a refusal of approval, are discussed below. Before that, the effect of changed leases or lease shares of the revenue is considered.

The above assumed value of $5.5 \%$ lease shares of the electricity revenue is a well-known value in practice. Depending on the bargaining position and outcome, however, the range extends much further. In the calculations made here, the lease share was increased to a value at which the profit (after taxes) between external investors and lessor would then be equally shared.

For the 2.3 MW wind turbine assumed here, a net present value of $€ 881,231$ could be achieved from personal investment, as already mentioned. For an external investor who leases the location of the windmill, the net present value decreases. The net present value of the lease income for the lessor of the site increases to the same extent (Figure 5). The value of $€ 592,514$ for the external investor and $€ 288,718$ for the lessor are shown in the chart for a lease share of $7 \%$ of the electricity revenue. At a lease height of slightly more than $10 \%$ of the electricity revenue of the wind turbine, external investors (fund) and lessors would share the expected surpluses (after tax).

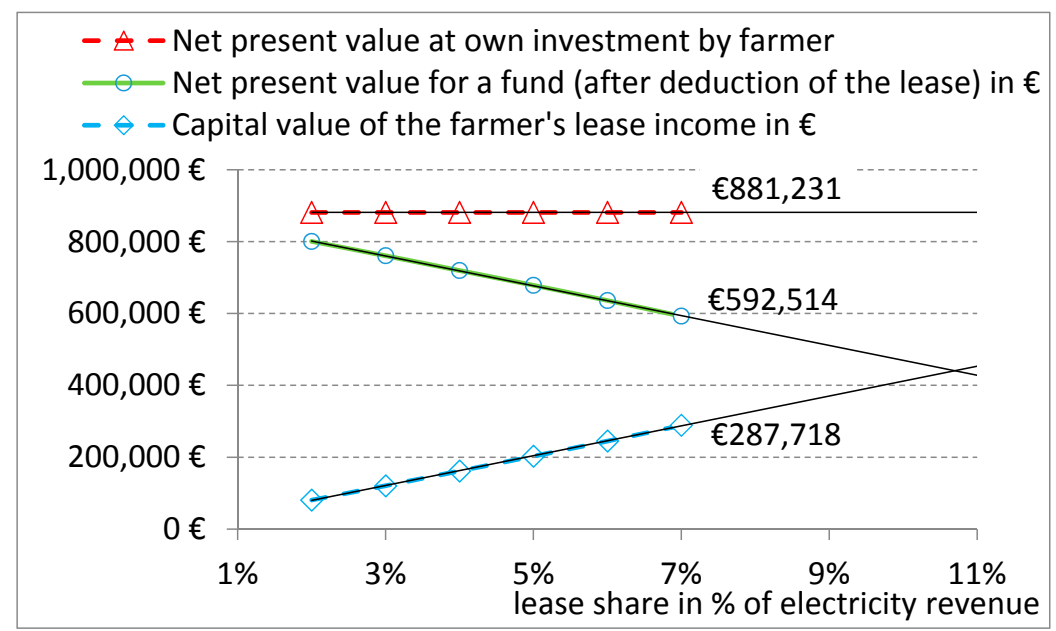

Figure 5. Net present values of the investment of a wind turbine in the case of personal investment by a farmer or an investment fund together with the net present value of the lease payments, the latter depending on the lease share of the electrical revenues. All values are after taxes. 
For all the calculations presented so far, it was assumed that sufficient equity would be available or could be procured from third parties through participation, and no risk at all was considered. The most important risks to be taken into account here would be, firstly, a fluctuating wind yield and, secondly, the planning costs for a later refusal of the building permit. The willingness to take risks for one's own investment certainly also depends on the expected rental income, because the higher the lease share from the electricity revenue, the less willing a farmer is to invest. In addition, liquidity aspects of the agricultural company should also be taken into account.

Furthermore, Reference [17] pointed out that various options must be taken into account when calculating the value of a wind turbine for the investee. It was shown that the instrument of real options emphasizes management flexibility, and that a higher capital value can be achieved in all cases chosen there (deferral, abandonment, and expansion) compared with the base case.

\section{Wind Turbines Pay off Even with Fluctuating Wind Yields}

The assumption was made that the utilization could vary by \pm 500 full-load hours, or $15.6 \%$ of the average $3200 \mathrm{~h}$ peak performance, according to a triangular distribution. Hence, the probability of a low performance of approximately $2700 \mathrm{~h}$ as well as a high performance of up to $3700 \mathrm{~h}$ is low. The other most important economic parameters for wind turbines are extremely stable due to the regulations of the Renewable Energy Sources Act (EEG, [3]) and, there are even regulations for wind-weak locations [3]. For the fluctuations in wind yield, 10,000 stochastic simulation runs [10] were calculated. The results showed that in $90 \%$ of cases, a net present value of between $€ 763,000$ and $€ 956,800$ can be achieved (Figure 6). The standard deviation was about $€ 60,000$, which is comparably small. The minimum of net present value was determined to be $€ 636,446$. Despite fluctuating wind yields in individual years, investing in wind turbines remains lucrative. It should be noted here that the revenue for a leased wind turbine location would also fluctuate according to the total revenue of the purchase of electricity. In the future, the risk of wind power will also be limited by the regulation of the remuneration according to the Renewable Energy Sources Act [3], by which surcharge values for electricity are to be applied in case of deviations from the reference location.

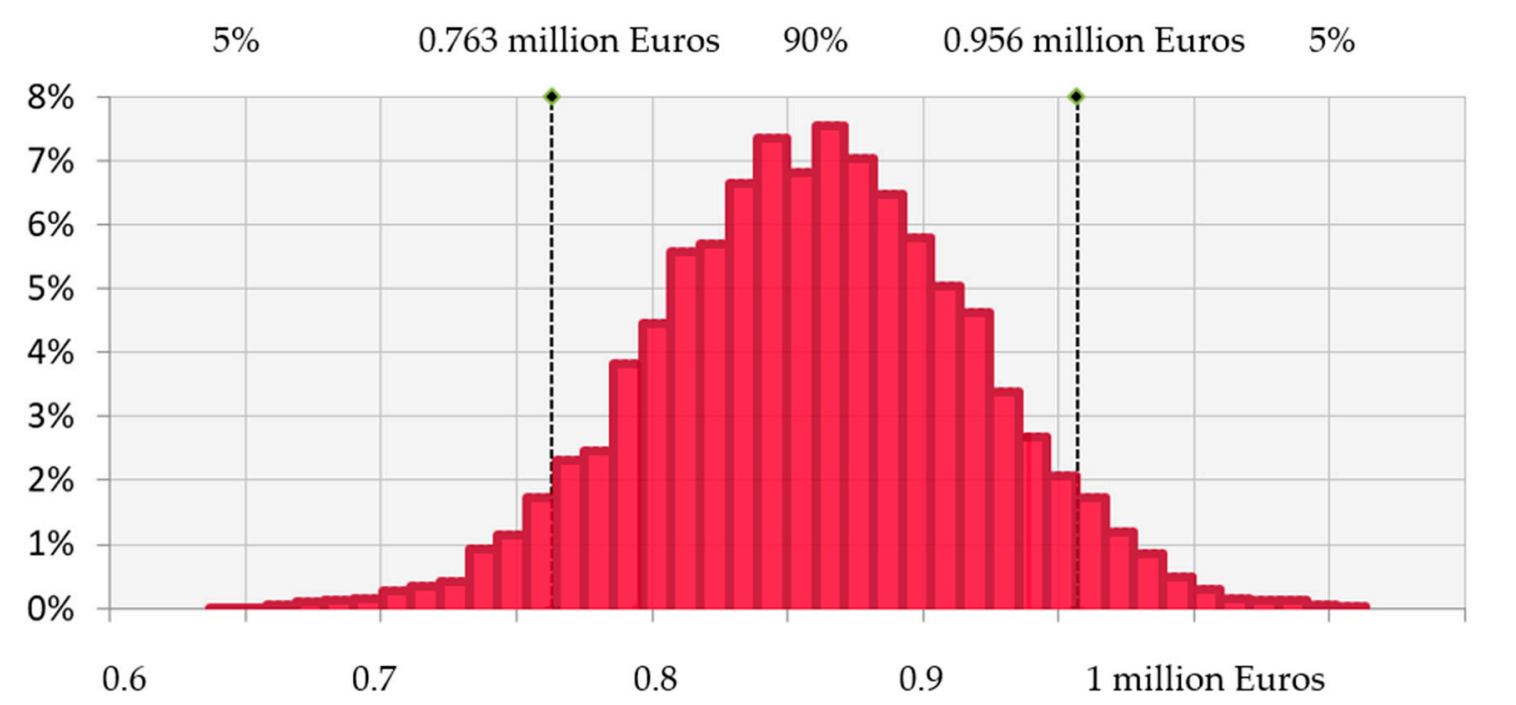

Figure 6. Distribution of the net present value in millions of Euros of one wind turbine with fluctuating full-load hours (peak performance of $3200 \pm 500 \mathrm{~h}$ as a triangular distribution, 10,000 simulations with @RISK).

However, how should one proceed if there is a new location to be developed and the planning phase of a wind turbine park is just at the beginning? In which cases should a single farmer take the risk of submitting an application? 


\section{Risks of Approval Must Be Included}

For the following risk assessments, it was assumed that sufficient equity was available. In this case, two factors are crucial: (1) That costs only arise at a considerable amount if the wind turbine is not approved; (2) that lease payments may be offered from an external investor-the investment fund. Both factors are connected, because the lower the rental income would be, the more likely an external investor would be willing to bear the risk of planning, while high contractually agreed and thus secure rental income would reduce the willingness to invest in a risky investment.

Thus, the expected results of the alternatives are known but not the probability of occurrence. With the help of the Hurwicz criterion [11], also called the optimism/pessimism rule, the subjective risk attitude of an investor can be taken into account in the decision. Conversely, for example, for the decision regarding "leasing the site" versus "building your own windmill", a recommendation depending on the risk attitude of the farmer can be given.

Table 3 shows again the values already shown in Figure 5. In addition, the threshold for the farmer's risk adjustment was calculated, taking into account that the maximum loss of $€-252,287$ for non-approval and the expected profit of $€ 881,231$ (net present value) would be equal to the rental income. The necessary risk-taking was estimated using the optimism parameter lambda according to Hurwicz, where $\lambda$ is between 0 for pessimists and 1 for optimists. For a given risk attitude, the net present value of the lease income should be equal to the surplus expected from investing in a wind turbine of one's own (Equation (1)). Equation 1 is the general formulation for calculating the equilibrium value for $\lambda$ :

Net present value of lease income $=$ loss of planning costs worst possible result $\times(1-\lambda)+$ Net present value of one's own wind turbine best possible result $\times \lambda$.

Table 3. Net present value of the investment of a wind turbine with $3200 \mathrm{~h}$ peak performance in the case of personal investment by a farmer (1) or an external investor (2) and the net present value of the leasing revenue (3) depending on the rent share of the electricity revenue after taxes and necessary risk tolerance for the investment in a personally owned wind turbine (4.1: $\lambda$ calculation according to Hurwicz); alternatively 4.2: $\lambda$ calculation according to Hurwicz for a peak performance of $3000 \mathrm{~h}$ p.a.).

\begin{tabular}{|c|c|c|c|c|c|c|}
\hline $\begin{array}{l}\text { (1) Net present value of personal investment by } \\
\text { farmer }\end{array}$ & \multicolumn{6}{|c|}{$€ 881,231$} \\
\hline $\begin{array}{l}\text { Maximum loss of planning costs in case of } \\
\text { non-approval }\end{array}$ & \multicolumn{6}{|c|}{$€-252,287$} \\
\hline $\begin{array}{l}\text { Rental percentage as a percentage of electricity } \\
\text { revenue }\end{array}$ & $0 \%$ & $1 \%$ & $3 \%$ & $5 \%$ & $7 \%$ & $10 \%$ \\
\hline $\begin{array}{l}\text { (2) Net present value of the fund (after } \\
\text { deduction of the lease) in } €\end{array}$ & 881,231 & 842,146 & 760,529 & 678,361 & 592,514 & 451,272 \\
\hline $\begin{array}{l}\text { (3) Net present value of the farmer's lease } \\
\text { income in } \epsilon^{*}\end{array}$ & 0 & 39,085 & 120,702 & 202,870 & 288,718 & 429,959 \\
\hline $\begin{array}{l}\text { (4.1) Risk setting: Breakeven with optimism } \\
\text { parameter }(\lambda) ; 3200 \text { h peak performance }\end{array}$ & 0.22 & 0.26 & 0.33 & 0.40 & 0.48 & 0.60 \\
\hline $\begin{array}{l}\text { (4.2) Risk setting: Breakeven with optimism } \\
\text { parameter }(\lambda) ; 3000 \mathrm{~h} \text { peak performance }\end{array}$ & 0.28 & 0.33 & 0.43 & 0.53 & 0.65 & 0.90 \\
\hline
\end{tabular}

* Note: The net present values after taxes take into account an income tax rate of approximately $45 \%$; should the lease income be taxed at a lower tax rate, then the net amount increases.

The method used to determine $\lambda$ is the Excel Solver routine for nonlinear optimization [18]. The higher the income from the lease, the more confident (optimistic) the farmer would have to be that he could beat the offer of an external investor (fund). Below, an example of the iteratively determined value for $\lambda$ is shown. For the $5 \%$ rent share of the electricity revenue for the $3200 \mathrm{~h}$ wind turbine peak 
performance, the corresponding $\lambda$ results in $\sim 0.4$, which is less than 0.5 , and thus suggests a slightly risk-averse setting (Equation (2)):

Net present value of lease income $€ 202,870=$ loss of planning costs of $€-252,287 \times(1-0.4)+$

Net present value of one's own wind turbine in the amount of $€ 881,231 \times 0.4$

where the exact value for $\lambda$ is 0.40154362879094 .

To be able to compare the results for other sites than the initial $3200 \mathrm{~h}$ peak performance site, an additional calculation was done for a less profitable wind turbine with only $3000 \mathrm{~h}$ peak performance (see 4.2 in Table 3). Here the values for $\lambda$ are slightly higher, which means that farmers would tend to be more risk alert, and more likely leasing their site rather than willing to invest into their personal wind turbines.

The range of the risk adjustment, measured as the Hurwicz criterion $\lambda$ is from 0.22 to 0.28 in the case for wind turbine sites which will not be leased due to the fact that there will be no revenue from leasing ( $0 \%$ of electricity revenue) and $\lambda$ increases to 0.60 to 0.90 in the case of higher percentages of electricity revenue.

From these calculations for the example of the $3200 \mathrm{~h}$ peak performance wind turbine, it can be concluded that, if there are low leasing offers due to the lack of external investors (fund), even a slightly optimistic but still rationally acting farmer $(\lambda=\sim 0.2)$ would be willing to take the risk of an investment due to the comparatively large expected returns. The higher the rent increases, the less willing the farmer will be to bear the risk, who will thus leave it to the external investors. Risk-neutral farmers $(\lambda=\sim 0.5)$ expect at least a share of $7 \%-8 \%$ of the electricity revenue. Optimistic, risk-taking farmers, on the other hand, would reject the offer even with higher rent offers and prefer to personally invest in a wind turbine on their own land (Figure 7). The less profitable wind turbine with only $3000 \mathrm{~h}$ peak performance assumes a higher risk tolerance to invest in a personal wind turbine for the same leasing earnings as a percentage of electricity revenue.

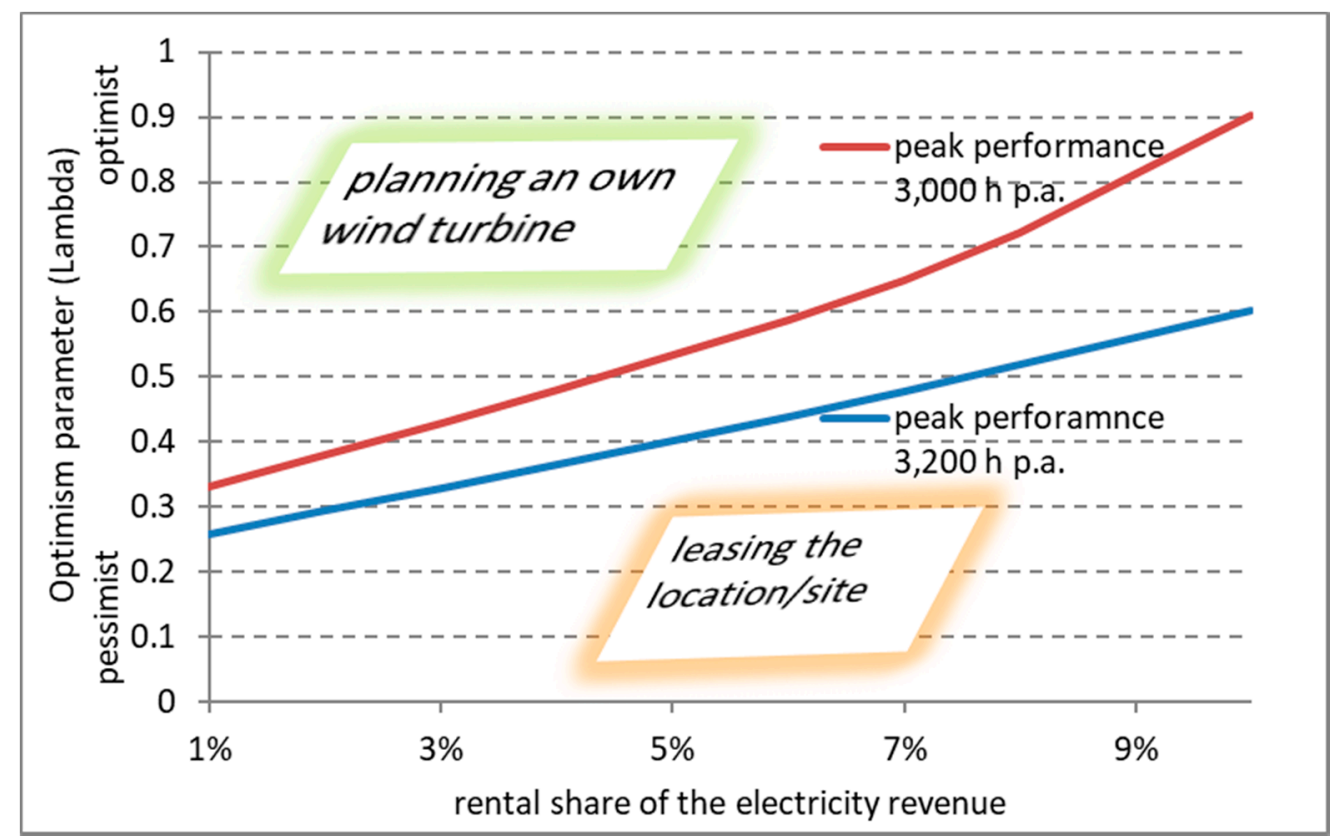

Figure 7. Decision to start planning wind turbines ( $3000 \mathrm{~h}$ or $3200 \mathrm{~h}$ peak performance) with an uncertain outcome compared with leasing the site depending on the rental share of the electricity revenue and the investor's risk attitude.

From the Renewable Energy Sources Act (EEG, [3]), granted feed-in tariffs support investment in wind turbines. The question therefore arises: Why do so few farmers invest in wind turbines? 
Reference [19], for example, found that when constructing a biogas plant, factors such as perceived land use competition and the opinion of the social environment had a significant impact on the farmer's investment decision. These aspects should also be considered for investments in wind turbines.

\section{Alternative Investment Options for Farmers}

In the last chapter of this article, the different influencing factors and risks are included and mirrored by the main factors and motivations in the decision-making process of farmers:

- $\quad$ risks of fluctuating wind yield

- $\quad$ risks of failed building permits and approval

- $\quad$ risk attitude of the investor and finally

- $\quad$ availability of equity.

The situation in eastern Germany, where the research area is located, is determined by special frame conditions due to the privatization policy after the reunification of Germany in 1990. Due to the privatization of state-owned land and private land sales, the land markets show a relatively high mobility in eastern Germany. For example, in 2015, the annual share of land purchased was (only) $0.35 \%$ in western Germany, while land mobility in eastern Germany reached $1.35 \%$ [20]. In the three decades since reunification, about one-third of the land changed owners and farmers; on average, the share of leased land has declined from $90 \%$ in 1990 to about 60\% in recent years in eastern Germany. The assumption is as follows: with a shortage of capital, farmers decided to purchase land to secure ownership instead of investing in wind turbines.

The statements made thus far make it clear that investing in wind turbines is relatively profitable, compared with returns that can be achieved in other farm businesses and rural areas. Three farmers with potential wind turbine sites were interviewed for this explorative study. The structured interview included the following topics:

1. Number and size of wind turbines already built or still in a planning phase (year of construction, self-built and/or leased)

2. Reasons to build a wind turbine, reasons to lease the site (leasing conditions, economy)

3. Integration of municipalities and citizens in the construction of wind turbines

4. Electricity power marketing

5. Future plans

Two of the farmers have themselves set up wind turbines and additionally leased locations. The third farmer has leased all sites to an investor in the region. The wind turbines were built in the years 2000/2001, 2013/2014, 2014/2015 and 2016. The size of the wind turbines is between 2.3 and $3.45 \mathrm{MW}$ and depends on the construction time of the wind turbines. The turbines constructed in 2000/2001 have an installed capacity of 2.3 MW. The two later built wind turbines have higher outputs.

As a reason for the lease of the location the third farmer argued about the necessary high share of equity (10\% the total investment) for the construction of an own wind turbine. The available capital was scarce at that time due to the purchase of farming land by the state's own agency (Bodenverwaltungsund verwertungsgesellschaft, BVVG). After the reunification in 1989/1990, the specific political situation in Germany was responsible for the limited time window for investments in farming land, when privatization of former "socialistic state" owned land took place. In the years 2000/2001, the investment in farming land was more important than the construction of wind turbines. In addition, leasing the site seemed less risky than owning it.

Farmers also acquired farming land from the BVVG in a first step and built wind turbines at a later date. The additional leasing of wind turbine locations suggests that the farmers thereby financially secure the investment of their own additional wind turbines. This, too, can be considered as a form of risk splitting. 
Concerning the topic "Integration of municipalities and citizens in the construction of wind turbines", which is part of the policy in the federal state of Mecklenburg-Western Pomerania, none of the farmers directly involved municipalities or citizens economically in the construction of wind turbines. The farmers who built wind turbines themselves provided funds to the communities, e.g., to support the renovation of a fire-fighting extinguishing pond and other equipment purchased for the fire department. One of the farmers provided the municipalities with financial means to develop their infrastructure. These payments consisted of one-time payments, which were negotiated during the approval phase. None of the farmers wanted to reveal the amount of these payments. Private individuals were not involved in the investments of wind turbines.

All of the electricity produced by the wind turbines is marketed and not taken for personal use. The reasons for this are the high production volumes and the low (own) on-farm consumption of electrical power. All of the produced electricity is fed into the transmission grid after deducting the personal electricity consumption and sold according to conditions of the Renewable Energy Sources Act (EEG [3]). Furthermore, no electricity is directly marketed to surrounding industrial and craft businesses.

One of the farmers, who owns land in a newly designated wind energy area is thinking of building even more wind turbines. Furthermore, he is also negotiating with investors about leasing the sites. At the present time, he plans to repower older wind turbines. The farmer, who has built only one wind turbine and leases more sites, will also have to choose between the alternative repowering or further operation of his wind turbine after the first 20 years of runtime. He then will do a market analysis and decide depending on the technical condition of his wind turbine. The farmer, who has leased all sites, has already agreed clauses in the lease agreement for the extension of the lease period. These can be extended by five years for the first construction phase, starting in 2000/2001 and five years in the second construction phase. The other two farmers must renegotiate with the investors at the end of their leases or renew existing contracts.

\section{Conclusions}

In summary, it can be stated that, besides the cost-effectiveness and profitability of wind turbines, other factors also play a key role. Land purchase competes very strongly with the construction of wind turbines. Often, the high equity ratio of $10 \%-15 \%$ of the investment volume deters the construction of wind turbines. The interviewed farmers did not build their own wind turbines at all designated sites, but in addition to their own wind power plants, leased additional sites. The risk can be reduced in this way, so that the decision to build one's own wind turbine is easier. The explorative survey has also shown that, so far, neither citizens nor communities are directly involved in the construction of wind turbines. Depending on their negotiating skills, communities could benefit from the construction of wind turbines in their respective district.

When considering investing in a wind turbine, one should first consider whether sufficient equity is available or whether additional external investors are needed. Furthermore, one must check to see if a building permit will be granted. The assessment of risk attitudes of farmers measured according to the Hurwicz criterion [11] moderates the decision-making process. In the case of uncertain planning projects and relatively high lease payments from electricity revenue, the alternative of "leasing the location" gains importance (Table 4). 
Table 4. Recommendations for investment decisions or leasing wind turbine sites depending on the state of the approval, the availability of equity capital, the risk adjustment, and the possible lease revenue (example for a $3200 \mathrm{~h}$ peak performance wind turbine).

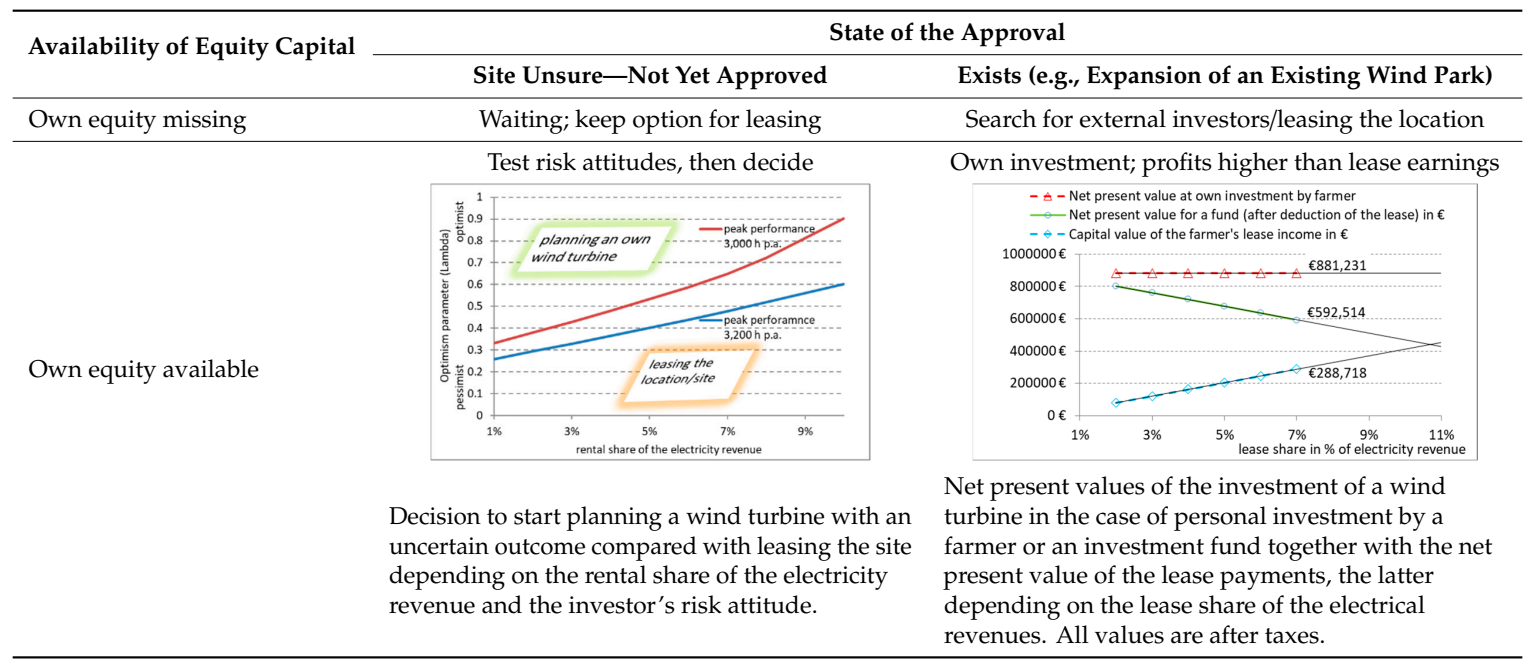

Author Contributions: All authors have equal contribution.

Funding: This project was financially supported by the University of Applied Sciences Neubrandenburg, as an internal university project.

Conflicts of Interest: The authors declare no conflict of interest.

\section{Abbreviations}

$\begin{array}{ll}\begin{array}{l}\text { Acronyms } \\ \text { BauGB }\end{array} & \begin{array}{l}\text { Description } \\ \text { Baugesetzbuch in der Fassung der Bekanntmachung vom 3. November 2017 (BGBl. I S. 3634) }\end{array} \\ \text { BImSchG } & \begin{array}{l}\text { Bundes-Immissionsschutzgesetz in der Fassung der Bekanntmachung vom 17. Mai 2013 (BGB1. } \\ \text { I S. 1274), das zuletzt durch Artikel } 3 \text { des Gesetzes vom 18. Juli 2017 (BGBl. I S. 2771) geändert } \\ \text { worden ist" }\end{array} \\ \text { BNatSchG } & \begin{array}{l}\text { Bundesnaturschutzgesetz vom 29. Juli 2009 (BGBl. I S. 2542), das zuletzt durch Artikel } 1 \text { des } \\ \text { Gesetzes vom 15. September 2017 (BGBl. I S. 3434) geändert worden ist" }\end{array} \\ \text { LuftVG } & \begin{array}{l}\text { Luftverkehrsgesetz in der Fassung der Bekanntmachung vom 10. Mai 2007 (BGBl. I S. 698), } \\ \text { das zuletzt durch Artikel 2 Absatz 11 des Gesetzes vom 20. Juli } 2017 \text { (BGBl. I S. 2808; 2018 I }\end{array} \\ & \begin{array}{l}\text { 472) geändert worden ist } \\ \text { UVPG }\end{array} \\ & \text { Gesetz über die Umweltverträglichkeitsprüfung in der Fassung der Bekanntmachung vom 24. } \\ & \text { Februar 2010 (BGBl. I S. 94), das zuletzt durch Artikel 2 des Gesetzes vom 8. September 2017 } \\ & \text { (BGBl. I S. 3370) geändert worden ist }\end{array}$

\section{References}

1. Commission of the European Communities. Communication from the Commission to the European Council and European Parliament: An Energy Policy for Europe; COM: Brussels, Belgium, 2007.

2. European Wind Energy Association (EWEA). Wind Energy and EU Climate Policy: Achieving 30\% Lower Emissions by 2020. Available online: http://www.ewea.org/fileadmin/ewea_documents/documents/ publications/reports/20110909_ClimateReport.pdf (accessed on 9 January 2019). 
3. EEG 2017. Gesetz für den Ausbau Erneuerbarer Energien, Erneuerbare-Energien-Gesetz vom 21. Juli 2014 (BGBl. I S. 1066), das Zuletzt Durch Artikel 2 des Gesetzes vom 22. Dezember 2016 (BGBl. I S. 3106) Geändert Worden ist. In English: Act on the Development of Renewable Energy Sources (Renewable Energy Sources Act -RES Act 2014) Unofficial Translation of the RES Act in the Version in Force as of 1 August 2014 (Based on the Bundestag Decisions of 27 June 2014 and 4 July 2014. This Version is not Authentic-Only the German Text as Published in the Federal Law Gazette is Authentic). Available online: https://www.erneuerbare-energien.de/EE/Redaktion/DE/Gesetze-Verordnungen/eeg_2014_engl.pdf (accessed on 15 April 2019).

4. Bundesverband der Energie-und Wasserwirtschaft e.V. (BDEW) 2016. Available online: https://www.bdew. de/media/documents/20160218_Foliensatz-Energie-Info-Erneuerbare-Energien-und-das-EEG-2016.pdf (accessed on 25 April 2019).

5. Statista. Available online: http://de.statista.com/statistik/daten/studie/20116/umfrage/anzahl-derwindkraftanlagen-in-deutschland-seit-1993 (accessed on 22 August 2018).

6. Marquardt, K. Landwirtschaftliche Windenergieanlagen-Entwicklung und Wirtschaftlichkeit. Master's Thesis, Hochschule Neubrandenburg, Neubrandenburg, Germany, 2018.

7. Bundesministerium für Ernährung und Landwirtschaft (BMEL 2017). Available online: https://www.bmel-forschung.de/fileadmin/SITE_MASTER/content/bilder/forschungsfelder/2017_4/ Landkarte_Volle_Kraft.pdf (accessed on 25 April 2019).

8. Statistical Office Mecklenburg-Western Pomerania. Statistical Yearbook; Mecklenburg-Vorpommern, S.A. (Hrsg.); Statistisches Amt Mecklenburg-Vorpommern: Schwerin, Germany, 2017; p. 443.

9. Degenhart, H.; Kowallik, J. Auswirkungen von Investitionen in Erneuerbare Energien (EE) auf Rentabilität und Risiko von Landwirtschaftsunternehmen aus kreditwirtschaftlicher Perspektive-Kreditprüfungsprozess und Rating bei Landwirtschaftsunternehmen mit Eneuerbaren-Energien-Anlagen; Berichte über Landwirtschaft; Band 96; Bundesministerium für Landwirtschaft und Ernährung: Bonn, Germany, 2018.

10. Graham, C.; Talay, D. Stochastic Simulation and Monte Carlo Methods-Mathematical Foundations of Stochastic Simulation; Springer: Berlin/Heidelberg, Germany, 2013.

11. Hurwicz, L. The Generalised Bayes Minimax Principle: A Criterion for Decision Making Under Uncertaint; Cowles Commission Paper 355; Yale University: New Haven, CT, USA, 1951; Available online: https: //cowles.yale.edu/sites/default/files/files/pub/cdp/s-0355.pdf (accessed on 25 April 2019).

12. Bolinger, M.; Wiser, R. A comparative analysis of business structures suitable for farmer-owned wind power projects in the United States. Energy Policy 2006, 34, 1750-1761. [CrossRef]

13. Munday, M.; Bristow, G.; Cowell, R. Wind Farms in Rural Areas: How Far Do Community Benefits from Wind Farms Represent a Local Economic Development Opportunity. J. Rural Stud. 2011, 27, 1-12. [CrossRef]

14. Zdravkovic, N. Willingness to Invest in Wind Energy-A Swedish Farmers' Perspective. Master's Thesis, Uppsala University, Uppsala, Sweden, 2013.

15. Hau, E. Windkraftanlagen; Grundlagen, Technik, Einsatz und Wirtschaftlichkeit (Bd. 5); Springer: Munich, Germany, 2014.

16. Deutsche Windguard GmbH. Kostensituation der Windenergieanlagen an Land in Deutschland. Available online: https://www.windguard.de/home.html (accessed on 25 April 2019).

17. De Mare, G.; Manganelli, B.; Nesticò, A. The Economic Evaluation of Investments in the Energy Sector: A Model for the Optimization of the Scenario Analyses. International Conference on Computational Science and Applications 2013, Part II LNCS; Murgante, B., Misra, S., Carlini, M., Torre, C., Nguyen, H.Q., Taniar, D., Apduhan, B.O., Gervasi, O., Eds.; Springer: Berlin/Heidelberg, Germany, 2013; Volume 7972, pp. 359-374. [CrossRef]

18. Ragsdale, C.T. Spreadsheet Modeling and Decision Analysis, 6th ed.; Cengage Learning; South-Western: Mason, OH, USA, 2011. 
19. Granoszewski, K.; Reise, C.; Spiller, A.; Mußhoff, O. The Role of Land Use Competition in Farmers' Engagement in Renewable Energy Production; Food and Agribusiness Program (FAUBA)_PENSA (USP): Buenos Aires, Argentina, 2011.

20. Böhme, K. Deutscher Landwirtschaftsverlag GmbH. In Bodenmobilität und Größe der Gehandelten Flächen in Deutschland; Briefe zum Agrarrecht Zeitschrift für Agrar-und Unternehmensrecht BzAR; Deutscher Landwirtschaftsverlag GmbH: Berlin, Germany, 2017; pp. 6-10.

(c)

(C) 2019 by the authors. Licensee MDPI, Basel, Switzerland. This article is an open access article distributed under the terms and conditions of the Creative Commons Attribution (CC BY) license (http://creativecommons.org/licenses/by/4.0/). 